ҚАЗАҚСТАН РЕСПУБЛИКАСЫ

ҰЛТТЫҚ ҒЫЛЫМ АКАДЕМИЯСЫНЫН

БАЯНДАМАЛАРЫ

ДОКЛАДЫ

НАЦИОНАЛЬНОЙ АКАДЕМИИ НАУК

РЕСПУБЛИКИ КАЗАХСТАН

\title{
REPORTS
}

OF THE NATIONAL ACADEMY OF SCIENCES

OF THE REPUBLIC OF KAZAKHSTAN

PUBLISHED SINCE 1944

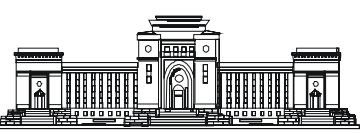




\author{
Ба с редак т о ры \\ х.ғ.д., проф., ҚР ҰҒА академигі \\ М.Ж. Жұрынов
}

Р едакция алқа сы:

\begin{abstract}
Адекенов С.М. проф., академик (Қазақстан) (бас ред. орынбасары)
Величкин В.И. проф., корр.-мүшесі (Ресей)

Вольдемар Вуйцик проф. (Польша)

Гончарук В.В. проф., академик (Украина)

Гордиенко А.И. проф., академик (Белорус)

Дука Г. проф., академик (Молдова)

Илолов М.И. проф., академик (Тәжікстан)

Кригер Виктор проф. (Германия)

Леска Богуслава проф. (Польша)

Локшин В.Н. проф., чЛ.-корр. (Қазақстан)

Нараев В.Н. проф. (Ресей)

Неклюдов И.М. проф., академик (Украина)

Нур Изура Удзир проф. (Малайзия)

Перни Стефано проф. (Ұлыбритания)

Потапов В.А. проф. (Украина)

Прокопович Полина проф. (Ұлыбритания)

Омбаев А.М. проф., корр.-мүшесі (Қазақстан)

Өтелбаев М.О. проф., академик (Қазақстан)

Садыбеков М.А. проф., корр.-мүшесі (Қазақстан)

Сатаев М.И. проф., корр.-мүшесі (Қазақстан)

Северский И.В. проф., академик (Қазақстан)

Сикорски Марек проф., (Польша)

Рамазанов Т.С. проф., академик (Қазақстан)

Такибаев Н.Ж. проф., академик (Қазақстан), бас ред. орынбасары

Харин С.Н. проф., академик (Қазақстан)

Чечин Л.М. проф., корр.-мүшесі (Қазақстан)

Харун Парлар проф. (Германия)

Энджун Гао проф. (Қытай)

Эркебаев А.Э. проф., академик (Қырғыстан)
\end{abstract}

«Қазақстан Республикасы Ұлттық ғылым академиясының баяндамалары»

ISSN 2518-1483 (Online),

ISSN 2224-5227 (Print)

Меншіктенуші: «Қазақстан Республикасының Ұлттық ғылым академиясы» Республикалық қоғамдық бірлестігі (Алматы қ.).

Қазақстан республикасының Мәдениет пен ақпарат министрлігінің Ақпарат және мұрағат комитетінде 01.06.2006 ж. берілген №5540-Ж мерзімдік басылым тіркеуіне қойылу туралы куәлік.

Мерзімділігі: жылына 6 рет.

Тиражы: 500 дана.

Редакцияның мекенжайы: 050010, Алматы қ., Шевченко көш., 28; 219, 220 бөл.; тел.: 272-13-19, 272-13-18, http://reports-science.kz/index.php/en/archive

(C) Қазақстан Республикасының Ұлттық ғылым академиясы, 2020

Типографияның мекенжайы: «NurNaz GRACE», Алматы қ., Рысқұлов көш., 103. 


\title{
Главны й редактор \\ д.х.н., проф., академик НАН РК \\ М. Ж. Журинов \\ Р едакци онная коллегия:
}

\author{
Адекенов С.М. проф., академик (Казахстан) (зам. гл. ред.) \\ Величкин В.И. проф., чл.-корр. (Россия) \\ Вольдемар Вуйцик проф. (Польша) \\ Гончарук В.В. проф., академик (Украина) \\ Гордиенко А.И. проф., академик (Беларусь) \\ Дука Г. проф., академик (Молдова) \\ Илолов М.И. проф., академик (Таджикистан) \\ Кригер Виктор проф. (Германия) \\ Леска Богуслава проф. (Польша) \\ Локшин В.Н. проф., чл.-корр. (Казахстан) \\ Нараев В.Н. проф. (Россия) \\ Неклюдов И.М. проф., академик (Украина) \\ Нур Изура Удзир проф. (Малайзия) \\ Перни Стефано проф. (Великобритания) \\ Потапов В.А. проф. (Украина) \\ Прокопович Полина проф. (Великобритания) \\ Омбаев А.М. проф., чл.-корр. (Казахстан) \\ Отелбаев М.О. проф., академик (Казахстан) \\ Садыбеков М.А. проф., чл.-корр. (Казахстан) \\ Сатаев М.И. проф., чл.-корр. (Казахстан) \\ Северский И.В. проф., академик (Казахстан) \\ Сикорски Марек проф., (Польша) \\ Рамазанов Т.С. проф., академик (Казахстан) \\ Такибаев Н.Ж. проф., академик (Казахстан), зам. гл. ред. \\ Харин С.Н. проф., академик (Казахстан) \\ Чечин Л.М. проф., чл.-корр. (Казахстан) \\ Харун Парлар проф. (Германия) \\ Энджун Гао проф. (Китай) \\ Эркебаев А.Э. проф., академик (Кыргызстан)
}

Доклады Национальной академии наук Республики Казахстан»

ISSN 2518-1483 (Online),

ISSN 2224-5227 (Print)

Собственник: Республиканское общественное объединение «Национальная академия наук Республики Казахстан» (г. Алматы).

Свидетельство о постановке на учет периодического печатного издания в Комитете информации и архивов Министерства культуры и информации Республики Казахстан №5540-Ж, выданное 01.06.2006 г.

Периодичность: 6 раз в год.

Тираж: 500 экземпляров

Адрес редакции: 050010, г.Алматы, ул.Шевченко, 28; ком. 219, 220; тел. 272-13-19, 272-13-18,

http://reports-science.kz/index.php/en/archive

(C) Национальная академия наук Республики Казахстан, 2020 г. 
Editorin chief

doctor of chemistry, professor, academician of NAS RK

M.Zh. Zhurinov

Editorial board:

Adekenov S.M. prof., academician (Kazakhstan) (deputy editor in chief)

Velichkin V.I. prof., corr. member (Russia)

Voitsik Valdemar prof. (Poland)

Goncharuk V.V. prof., academician (Ukraine)

Gordiyenko A.I. prof., academician (Belarus)

Duka G. prof., academician (Moldova)

Ilolov M.I. prof., academician (Tadjikistan)

Krieger Viktor prof. (Germany)

Leska Boguslava prof. (Poland)

Lokshin V.N. prof., corr. member (Kazakhstan)

Narayev V.N. prof. (Russia)

Nekludov I.M. prof., academician (Ukraine)

Nur Izura Udzir prof. (Malaysia)

Perni Stephano prof. (Great Britain)

Potapov V.A. prof. (Ukraine)

Prokopovich Polina prof. (Great Britain)

Ombayev A.M. prof., corr. member (Kazakhstan)

Otelbayv M.O. prof., academician (Kazakhstan)

Sadybekov M.A. prof., corr. member (Kazakhstan)

Satayev M.I. prof., corr. member (Kazakhstan)

Severskyi I.V. prof., academician (Kazakhstan)

Sikorski Marek prof., (Poland)

Ramazanov T.S. prof., academician (Kazakhstan)

Takibayev N.Zh. prof., academician (Kazakhstan), deputy editor in chief

Kharin S.N. prof., academician (Kazakhstan)

Chechin L.M. prof., corr. member (Kazakhstan)

Kharun Parlar prof. (Germany)

Endzhun Gao prof. (China)

Erkebayev A.Ye. prof., academician (Kyrgyzstan)

Reports of the National Academy of Sciences of the Republic of Kazakhstan.

ISSN 2224-5227

ISSN 2518-1483 (Online),

ISSN 2224-5227 (Print)

Owner: RPA "National Academy of Sciences of the Republic of Kazakhstan" (Almaty).

The certificate of registration of a periodic printed publication in the Committee of Information and Archives of the Ministry of Culture and Information of the Republic of Kazakhstan N 5540-Ж, issued 01.06.2006.

Periodicity: 6 times a year.

Circulation: 500 copies.

Editorial address: 28, Shevchenko str., of. 219, 220, Almaty, 050010, tel. 272-13-19, 272-13-18, http://reports-science.kz/index.php/en/archive

(C) National Academy of Sciences of the Republic of Kazakhstan, 2020

Address of printing house: «NurNaz GRACE», 103, Ryskulov str, Almaty. 


\title{
Geography and cartography
}

\author{
REPORTS OF THE NATIONAL ACADEMY OF SCIENCES \\ OF THE REPUBLIC OF KAZAKHSTAN \\ ISSN 2224-5227 \\ https://doi.org/10.32014/2020.2518-1483.30
}

Volume 2, Number 330 (2020), $41-48$

ГРНТИ 36.33 .27

A.G. Gabdykadyr ${ }^{1}$, G.T. Issanova ${ }^{1,2}$, Y.Kh. Kakimzhanov ${ }^{1}$, Long $\mathrm{Ma}^{3}$

${ }^{1}$ Al-Farabi Kazakh National University, Faculty of Geography and Environmental Sciences, Almaty, Kazakhstan;

${ }^{2}$ Research Centre of Ecology and Environment of Central Asia, Almaty, Kazakhstan;

${ }^{3}$ Xinjiang Institute of Ecology and Geography, Chinese Academy of Sciences, China.

E-mail: gabdykadyr@inbox.ru,gul_nur.777@mail.ru,erka_7717@mail.ru,malong@ms.xjb.ac.cn

\section{ANALYSIS OF SOIL DEGRADATION AND DESERTIFICATION IN SOUTHERN BALKASH DESERT BASED ON GIS}

\begin{abstract}
Desertification and degradation provide a clear picture of global environmental and socio-economic issues. Most of Kazakhstan is located in a desert region, including the suburbs of South Balkhash. The reason is that desertification of the region has a strong influence on natural and anthropogenic factors.

To consider the geomorphological state of the region and the problem of desertification of the territory, it is necessary to determine the importance of the process of relief of geological structure and relief of tectonics. In recent years, the environmental situation in Balkhash has deteriorated sharply not only as a result of river flow regulation, but also as a result of non-commercial economic activities. Therefore, it is very important to assess the situation of desertification and degradation in the Balkhash region. Desert vegetation has been identified, since information in the spectral range is often insufficient to describe the state of plants, plant indices often develop by combining two or more spectral bands. Land cover index is the percentage of vegetation over a given surface area. Remote sensing information was used to detect the entire land cover. Remote sensing with time and space limitations is widely used to classify vegetation cover. In this work, the proportion of vegetation was estimated by NDVI. The proportion of land cover is based on the relationship between NDVI (NDVIS) and NDVI (NDVIV) in the soil. Using the NDVI index, land cover zones were determined based on satellite images of 2006 and Landsat-5 from 2011. TCT (Tasseled Cap Transformation) coefficients are used in the widest range of problems solved using Earth remote sensing data: from recognition of the coastline of water bodies to determination of forest disturbances. Stressful vegetation may be an indirect sign of the presence of salt in soils. Saline soils are usually characterized by poorly planted areas. A normalized differential salinity index (NDSI) was also determined.
\end{abstract}

Key words: degradation, desertification, satellite images, Landsat-5, NDVI.

Introduction. Scientists have used various methods to study deserts. The methods used vary widely depending on the availability of information. The first researchers of the Balkhash region were such naturalists as: A.A. Babkov [1], I.V. Mushketov [2], V. Fisher [3], A.M. Nikolsky [4], G. Karelin, B.F. Meffert [5-6].

"Assessment of the geoecological state of Balkhash". T. Tilekova, M.T. Oshakbaev, A.P. Haustov, 2016. The current environmental problems of the Balkhash region are considered. An assessment is made of the ecological condition of the territory and water resources, among which Lake Balkhash, the Ili, Karatal, Lepsy rivers are identified as the most polluted. The necessity of geoecological monitoring, as well as comprehensive measures to maintain the stability of the Balkhash level, prevent water pollution, protect floodplains of lakes, preserve floodplain forests and saxaul plantations, control desertification processes, is justified. The main pollutants are mining, utilities, the impact of human settlements and agrocenoses, in particular, irrigated agriculture. As a result of the study, it was found that all landscapes in the region underwent changes caused by anthropogenic impact, and are anthropogenically modified natural landscapes [7].

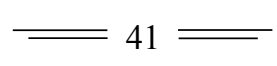


"Formation of anthropic soils in agricultural areas of the south of Balkhash (south of Kazakhstan)" Tazabekova E.T., Usen Azina, 2015. The ecological assessment of the current state of breeding systems is given [6].

"Geographic Information System (GIS) with integrated models: a new approach to assessing the vulnerability and risk of desertification in Sardinia (Italy)" Paola Molinari. The DPSIR (Driving ForcesPressure-State-Impact-Response) category is used to classify desertification indicators. The desertification index (IDI) was classified according to five risk levels, and the results of field studies were tested in areas selected as areas with high risk areas. "Desertification monitoring using satellite imagery LANDSAT TM" Methods of Wu-Kyun Lee, Du-An Kwak, Sungho Choi, JeonheolLiTwo were used to determine the desertification process. First, the extent and tendency of desertification was determined by classifying the soil cover into four different categories using the Plant Index (NDVI): water-logged desert zone, a partially recorded sand zone, a recorded sand zone and pastures. Secondly, the desertification classification was classified by the Plant Index (ICAID): state of nature, latent state, weak desertification, moderate desertification and high desertification level [8].

"Terrestrial and satellite studies of the productivity of pasture republics of Kalmykia with an affordable degree of degradation of plant communities" A.N. Zolotokrylin, T.B. Titkova, S.S. Ulanova, N.L. Fedorov, 2013.

Using satellite data from NDVI MODIS and NDVI ETM + Landsat-7, we studied the space variations in productivity, identified areas other than the degree of degradation, estimated the correlation between the values of NDVI and the productivity of desert phytocenoses, measured by the number of available methods [9].

"Regional manifestation of global desertification in the north-west of the Caspian Sea" K.M. Petrov, V.A. Bananova, V.G. Lazareva, A.S. Unagaev, 2016. Degradation of vegetation, condition of lands and irrigation systems, fluctuations in the level of the Caspian Sea, development of transport networks, cities and towns in the region are used as objects for monitoring levels of destruction of the natural environment. The concept of cartographic monitoring of degradation of arid ecosystems is discussed and a map of the modern desertification of the Northwest Para-Caspian is proposed. Thanks to GIS technologies, the map can be updated taking into account the dynamic processes of land degradation [10].

"Development of an algorithm for assessing the degree of soil degradation from a multispectral image" V.G. Bondur, A.B. Murynin, A.A. Richter, M.A. Shahramanyan. An algorithmic assessment of the degree of soil degradation using aerospace images is described. A block diagram of a software module that implements the proposed algorithm is presented. An example of the study of soil degradation during littering in areas of large urban landfills is given [11].

The reason of formation of the centers of the mobile sandy barkhans formed as a result of anthropogenic degradation of sandy soils of desert rangelands of SouthernLake Balkhash region is studied. The main soil-hydrological properties the $0-60 \mathrm{~cm}$ a layer of a sandy barkhan of friable-sandy granulometric composition with absolute prevalence of fine sandy fraction ( $>90 \%$ ), having very high speed of absorption $(8.1 \mathrm{~m} / \mathrm{min})$, filtrations $(2,1 \mathrm{~mm} / \mathrm{min})$, minimumwater capacity (MWC) $-7.3 \%$ and wilting moisture (WM) $1.7 \%$ are defined. Features of the seasonal regime of field moisture of a sandy barkhan, characterized maximum moisture $(5,6 \%)$ during the early-spring period, the beginning of deficiency of moisture $(\sim 2 \%)$ in June and acute shortage of moisture in July, August and in September with moisture of all thickness of a root zone below WM are established [12].

The article provides the data of the seasonal hydrothermal regime of the centers of the mobile barchans formed from sandy soils as a result of anthropogenic degradation, which were widely spread in Southern Balkhash region [13].

Aim of the research.Balkash is a closed semi-freshwater lake in the Balkash-Alakol depression in southeastern Kazakhstan, the second largest non-drying salt and the 14th in the list of the largest lakes in the world (figure 1) [14].

Absolute elevations of the earth's surface vary from $340 \mathrm{~m}$ to $500-600 \mathrm{~m}$. The northern and western border of the basin is Lake Balkhash. From the south and east it borders with the spurs of the Zhongar Alatau, and from the southwest it borders with the Shu-Ili mountains [15]. The Early Paleozoic 
successions dated by the Cambrian are known in the northwest of the Balkhash lake. This vast area was named the Atasu-Zhamshi watershed [1], that is, thearea located between the rivers Atasu and Mointy. In geological literature, one can find also anothernaming of the Atasu-Mointi watershed[16].The southern Balkhash region is divided into western and eastern parts. On the left bank of the Ili river basin, the Taukum and Moiynkum deserts, and in the middle of the Ili and Karatal rivers - the Saryesik-Atyrau desert. In the east, between the Karatal and Aksu, Zhamanzhal and Lyukum sands and Aral rivers on the lower bank of Aksu and the Lepsy river. The arid climate of the region is characterized by desert landscapes [14]. Balkhash region is mining large-scale polymetallic ores, coal, building materials. Traditionally, large areas were used for pasture. In the region, $16 \%$ of industrial production and $13 \%$ of agricultural production in Kazakhstan, fishing accounts for more [17].

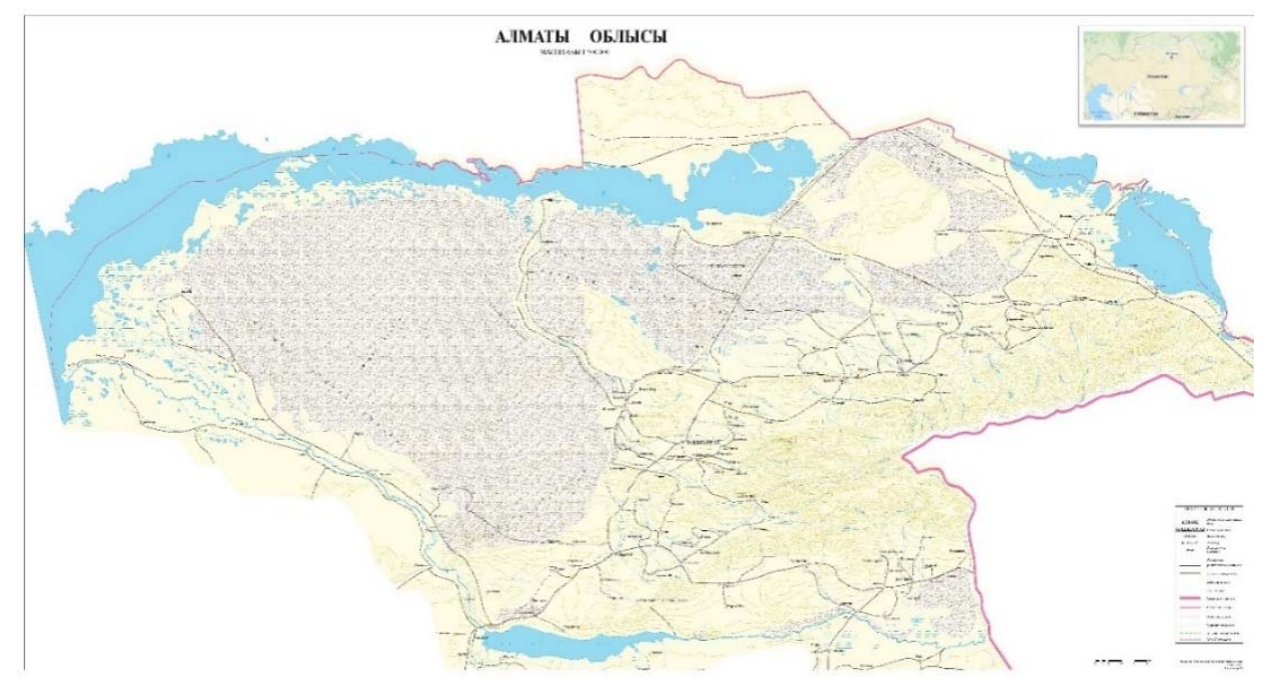

Figure1 - Study area- Southern Balkash Desert

The featureless relief. The climate is continental. Winter is cold, summers are hot, arid. The average temperatures in January are $13-15{ }^{\circ} \mathrm{C}$, July $24^{\circ} \mathrm{C}$. The average annual rainfall is $100-150 \mathrm{~mm}$ [18]. The largest river is Ili with a length of $1001 \mathrm{~km}$. On its right bank laid Akdalinsky irrigation system. Numerous bakanas are old dried river beds. On the territory of the district is the Karoy state reserve with an area of 509 thousand hectares. The main soil cover: takyr-like soils and sands on which saxaul, meadowsweet, jujube, wormwood, cheegrass, sedge and others grow. There are wolf, fox, badger, hare, roe deer, saiga, wild boar, muskrat are found in dense reeds. Pheasants, partridges are found in floodplains and river valleys; on ponds - cranes, pelicans, flamingos, etc.; in reservoirs: carp, crucian carp, perch, marinka.

Deposits of coal, manganese and uranium have been explored in the bowels of the Balkhash region. Marble and granite are mined at the Zhalpaktas deposit. In addition, there are deposits of salt, building sand and clay for the production of bricks. All settlements are located in the valley of the Ili River. The basis of the region's economy is agriculture. In crop production - irrigation and rainfed farming (wheat, rice, vegetables and potatoes). The main areas of livestock breeding are sheep breeding, cattle breeding, horse breeding. In the lower reaches of the Ili River, shipping is developed [19].

Materials and methods. The calculation of the normalized differential vegetation index (NDVI), which is available on the fly, comes first. In addition, NDVI is often used around the world to monitor drought, forecast agricultural production, assist in forecasting fire zones and desert attack maps. NDVI is preferred for global monitoring of vegetation, since it helps to compensate for changes in lighting conditions, surface slope, exposure, and other external factors (Figure2) [20].

NDVI is calculated by the formula:

$$
\text { Proportion of vegetation cover }=\frac{(\text { NIR-Red })}{(\text { NIR }+ \text { Red })}
$$

NIR - reflection in the near infrared spectrum

RED - reflection in the red region of the spectrum 


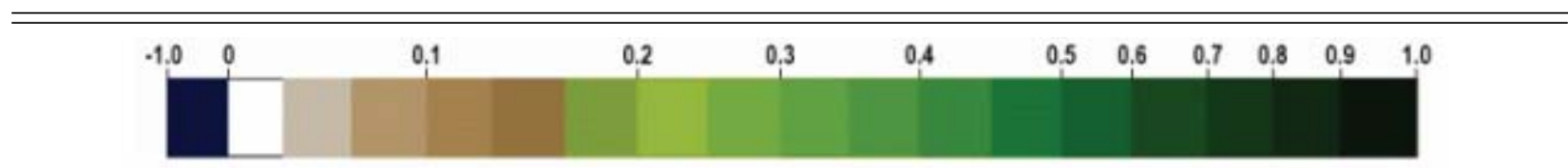

Figure 2 - Discrete NDVI Index Scale

The main research method was the analysis of the normalized relative vegetative index (NDVI Normalized Difference Vegetation Index), which was first described by B. J. Rouse in 1973[21].

TCT (Tasseled Cap Transformation) coefficients are used in the widest range of problems solved using Earth remote sensing data: from recognition of the coastline of water bodies to determination of forest disturbances [22]. This technique uses the Brightness coefficient TCT.Tasseled Cap Transformation (TCT) is calculated by the formula (table 1 ).

Table 1 - The calculation formula Tasseled Cap Transformation (TCT) (Healey S.P., et al, 2005).

\begin{tabular}{|l|l|}
\hline \multicolumn{1}{|c|}{$\begin{array}{c}\text { Tasseled } \\
\text { Cap } \\
\text { Transformation }\end{array}$} & \multicolumn{1}{c|}{ Formula } \\
\hline Brightness & $0.3037 *(\mathrm{~b} 1)+0.2793 *(\mathrm{~b} 2)+0.4743 *(\mathrm{~b} 3)+0.5585 *(\mathrm{~b} 4)+0.5082 *(\mathrm{~b} 5)+0.1863 *(\mathrm{~b} 7)$ \\
\hline Green & $0.2848 *(\mathrm{~b} 1)-0.2435 *(\mathrm{~b} 2)-0.5436 *(\mathrm{~b} 3)+0.7243 *(\mathrm{~b} 4)+0.0840 *(\mathrm{~b} 5)-0.1800 *(\mathrm{~b} 7)$ \\
\hline Humidity & $0.1509^{*}(\mathrm{~b} 1)+0.1973 *(\mathrm{~b} 2)+0.3279 *(\mathrm{~b} 3)+0.3406 *(\mathrm{~b} 4)-0.7112 *(\mathrm{~b} 5)-0.4572 *(\mathrm{~b} 7)$ \\
\hline
\end{tabular}

Salting of soil is the process of enriching the soil with soluble salts, which leads to obtaining information about the soil exposed to salt. Soil salinization in irrigated areas is becoming a serious problem for agriculture. Saline soil conditions have reduced the value and productivity of large areas of land around the world [23]. The main problems associated with arid and semi-arid areas are salinization and desertification. Irrigational evaporation of moisture from the surface or shallow depths within the profile and insufficient annual precipitation for leaching salts from the rooting zone of plants contribute to the excessive accumulation of soluble salts in soils of arid and semi-arid regions, which makes such lands with minimal success. Sixteen different spectral salinity indices developed in numerous studies related to salt detection and soil salinity mapping were studied for all Landsat images and seven salinity indices were most commonly used (NDSI, SI 1, SI 2, SI 4, SI 9, SI 10, SI 14) taken into account in this study are shown in table 2 [24]. The digital elevation model (DEM) can also be used to predict soil salinization taking into account the variographic morphology of the earth's surface in order to increase the accuracy of its prediction [25].

Table 2 - The most common salinity indicators [26]

\begin{tabular}{|l|l|l|}
\hline \multicolumn{1}{|c|}{ Salinity indices } & \multicolumn{1}{c|}{ Equation } & \multicolumn{1}{c|}{ Reference } \\
\hline Normalized Differential Salinity Index & NDSI $=\frac{(R-N I R)}{(R+N I R)}$ & (Khan, Rastoskuev et al. 2001) \\
\hline Salinity Index 1 & SI $=\sqrt{B \times R}$ & (Khan, Rastoskuev et al. 2001) \\
\hline Salinity Index 2 & SI $=\sqrt{G \times R}$ & (Douaoui, 2006) \\
\hline Salinity Index 4 & SI $4=\sqrt{G^{2}+R^{2}}$ & (Bannari, Guedon et al. 2008) \\
\hline Salinity Index 9 & SI9 $=\frac{\left(B_{5} \times B_{6} B_{6} \times B_{6}\right.}{B_{5}}$ & (Abbas, 2007) \\
\hline Salinity Index 10 & SI10 $=\frac{B}{R}$ & (Abbas, 2007) \\
\hline Salinity Index 14 & SI14 $=\frac{R \times N I R}{G}$ & \\
\hline
\end{tabular}

For the tasks of determining the degree of salinization of the soil cover of the project territories, as one of the factors of desertification, it is recommended to use this index during monitoring [23].

Results and discussion. Landsat TM data for 2006 and 2011 were taken for this research (table 4, figure 3). The image has seven bands with a resolution of $30 \mathrm{~m}$ pixels. Image analysis was performed using ArcGIS 10.3. 
Table 4 - Data used

\begin{tabular}{|c|c|}
\hline Image & Image data \\
\hline Landsat TM5 & $09.09 .2006 ; 02.09 .2006 ; 11.09 .2006 ; 19.09 .2006$ \\
\hline Landsat TM5 & $07.09 .2011 ; 15.09 .2011 ; 08.09 .2011 ; 18.09 .2011$ \\
\hline
\end{tabular}

The stage of Earth remote sensing data analysis, the main task of which is the recognition and identification of objects detected in the image, is called image decryption.

For Landsat-5 images, in accordance with the process of soil degradation, salinization, and desertification, the interpretation of these channel combinations was chosen, i.e., the color combination 7.5.3. This combination gives an image close to natural colors, but at the same time allows you to analyze the state of the atmosphere and smoke. Healthy vegetation looks bright green, grassy communities look green, bright pink areas detect open soil, brown and orange tones are typical for sparse vegetation. Dry vegetation looks orange, water - blue. Sand, soil and minerals can be represented by a very large number of colors and shades. This combination gives an excellent result in the analysis of deserts and desertified territories [27].

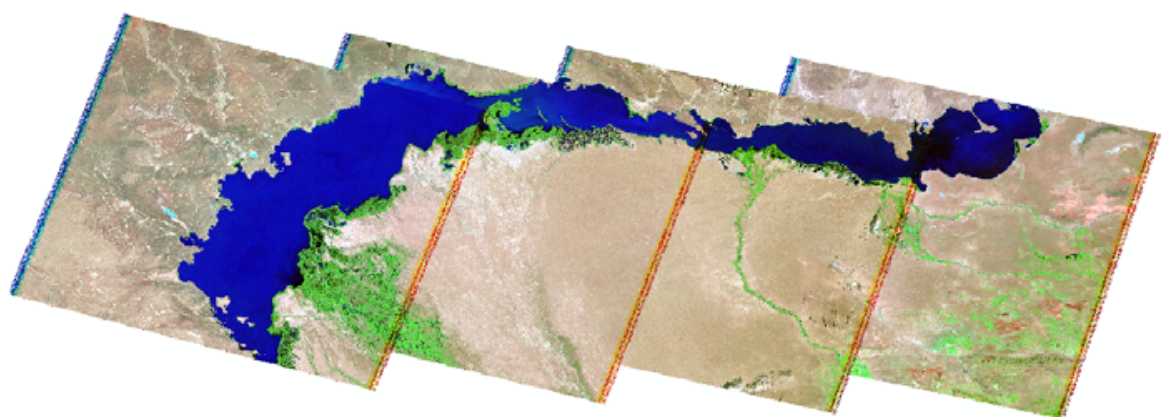

Figure 3 - Satellite image of the Southern Balkash Desert (Landsat TM5)

The formula used to calculate the NDVI of the study area:

$$
\text { NDVI }=\frac{(\text { BAND4-BAND3) }}{(\text { BAND4+BAND3) }}
$$

The formula used to calculate the SI2 of the study area:

$$
\text { SI2 }=\sqrt{\text { band } 2 \times \text { band } 3}
$$

The formula used to calculate the TCT (Tasseled Cap Transformation) of the study area:

$$
T C T=0.304 * \mathrm{~b} 1+0.279 * \mathrm{~b} 2+0.474 * \mathrm{~b} 3+0.559 * \mathrm{~b} 4+0.508 * \mathrm{~b} 5+0.186 * \mathrm{~b} 7
$$

As a result, the map "Degradation map of desert soils of the South Balkash region, 2006" and the Degradation map of desert soils of the South Balkash region, 2011" was compiled on a scale of 1: 2500000 (figures 4, 5).

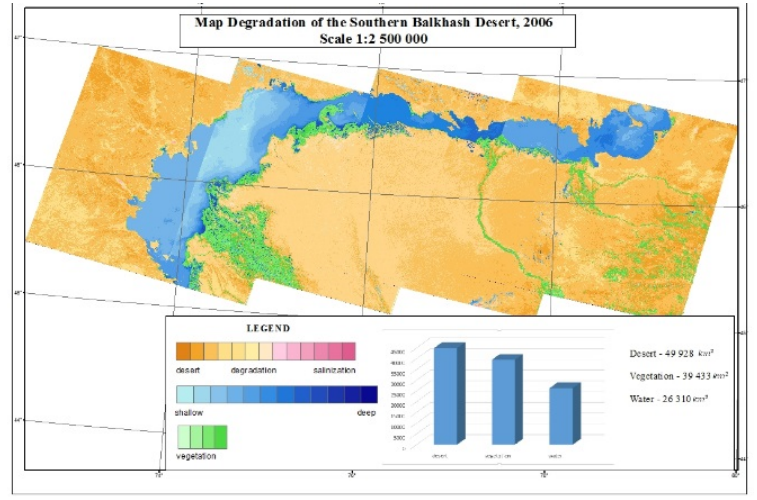

Figure 4 - Soildegradation map of the Southern Balkash deserts based on GIS, 2006

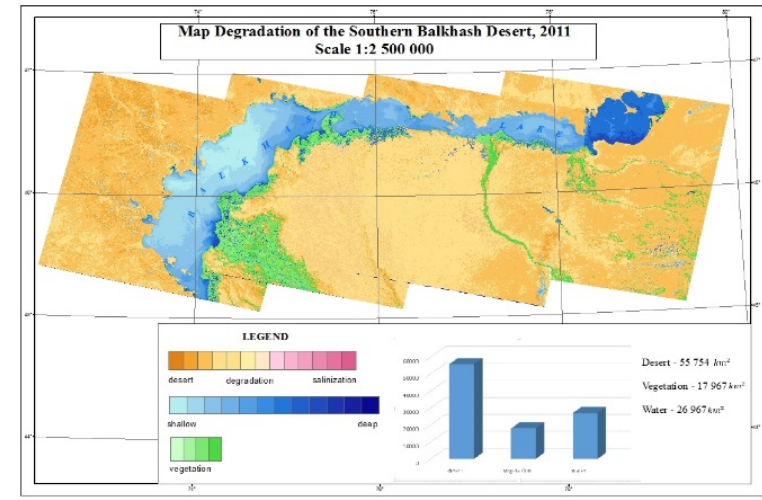

Figure 6 - Soil degradation map of the Southern Balkash deserts based on GIS, 2011 
The obtained values of NDVI, SI, TCT are varied (table 5). We showed this difference in the form of diagrams (figures 7, 8). For example, if in 2006 the total area of SI was $49928 \mathrm{~km}^{2}$, and in 2011, the total area was $55754 \mathrm{~km}^{2}$. NDVI in 2006 was $39433 \mathrm{~km}^{2}$, and in 2011, the area was reduced to $17967 \mathrm{~km}^{2}$.

Table 5 - The obtained values of NDVI, SI, TCT

\begin{tabular}{|c|c|c|}
\hline Index & 2006 & 2011 \\
\hline SI & $49928 \mathrm{KM}^{2}$ & $55754 \mathrm{KM}^{2}$ \\
\hline NDVI & $39433 \mathrm{KM}^{2}$ & $17967 \mathrm{KM}^{2}$ \\
\hline TCT & $26310 \mathrm{KM}^{2}$ & $26975 \mathrm{KM}^{2}$ \\
\hline
\end{tabular}

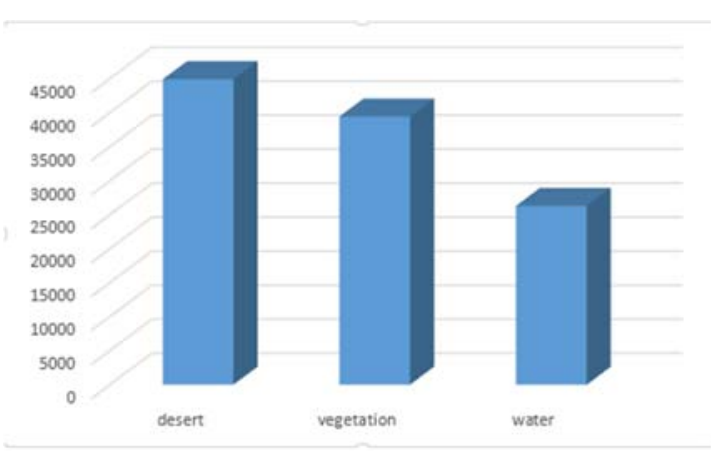

Figure 7 - The calculatedindixes, 2006

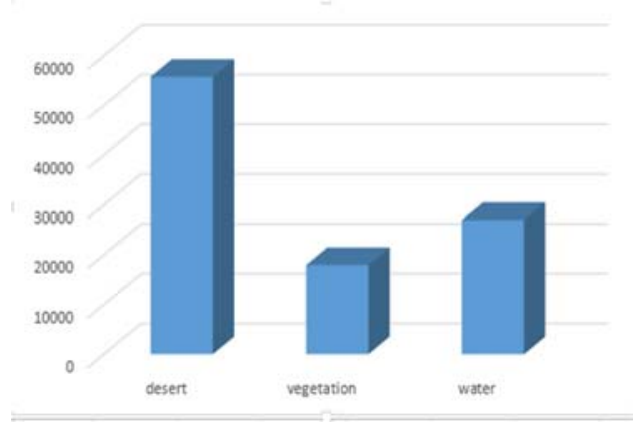

Figure 8- The calculatedindixes, 2011

Conclusions. Most part of the study area has been changed to a high level of desertification and an average level of degradation. You can use images taken at different times, which leads to some seasonal differences in the vegetation cover. Such differences could affect the comparison of desertification rates from 2006 to 2011.

This study performed several tasks related to degradation and desertification. The main tasks are to identify plant indices and vulnerability to soil erosion, and the degree of salinity. In the Southern Balkhash desert, we can observe a relative decrease in the distribution of vegetation based on biennial satellite imagery through NDVI, which has a different standardized vegetation index. In addition, the main problems associated with arid and semi-arid areas are salinity (NDSI) and desertification. The obtained values of NDVI, NDSI are varied. We showed this difference in the form of diagrams. For example, if in 2006 the total area of NDSI was $49,928 \mathrm{~km}^{2}$, and in 2011 , the total area was $55,754 \mathrm{~km}^{2}$.

This index classification is a natural histogram breakdown algorithm (which determines gaps between classes, which divide the same values into groups and maximize differences between classes). The prevalence of vegetation cover, the risk of soil erosion and the results have been summarized.

\section{А.Ғ. Ғабдықадыр ${ }^{1}$, Г.Т. Исанова ${ }^{1,2}$, Е.Х. Какимжанов ${ }^{1}$, Лонг Ма $^{3}$}

1 Әл-Фараби атындағы қазақ ұлттық университеті,

География және табиғатты пайдалану факультеті, Алматы, Қазақстан;

1,2 Орталық Азия экология және қоршаған орта ғылыми-зерттеу орталығы, Алматы, Қазақстан;

${ }^{3}$ Синьцзян экология және география институты, Қытай ғылым академиясы, Қытай

\section{ОНТУСТІК БАЛКАШ ШӨЛІНІН ТОПЫРАҚ ДЕГРАДАЦИЯСЫН ЖӘНЕ ШӨЛДЕНУІН ГАЖ АРҚЫЛЫ ТАЛДАУ}

Аннотация. Шөлдену және топырақ деградациясы жаһандық экологиялық және әлеуметтік-экономикалық мәселелердің айқын көрінісін білдіреді. Шөл аймақтарының пайда болуына климаттың аридтілігі, топырақтың және өсімдіктің дефляциялық және эрозиялық әректтері нәтижесінде беткі бедердің бұзылуы, эолдық үдерістердің қарқындылығы және тағы басқа табиғи факторлар ғана әсер етіп қоймай, антропогендік іс-әрекеттердің, яғни егістік және жайылым жерлерді тиімсіз пайдалану, су ресурстарын ысырапсыз пайдалану сияқты жағдайлар да табиғатқа кері ықпалын тигізіп жатыр.

Шөлейттену - табиғат пен табиғаттың қолайсыз құбылыстары, бір-бірін нығайтатын табиғат ортасы сипаттамаларының өзгеруіне әкелетін ұзақ тарихи үдерістің нәтижесі. Қазақстанның көп бөлігі шөл 
аймағында жатыр, соның ішінде Оңтүстік Балқаш маңы аумағын ерекше атап айтуға болады. Себебі бұл өңірдің шөлденуіне табиғи және антророгендік факторлар қатты әсер етіп отыр. Бұл зерттеу жұмысында шөлдің өсімдік жамылғысын талдау нәтижелері қарастырылды. Өсімдіктердің жай-күйін сипаттау үшін бір спектральды диапазондағы ақпарат әдетте жеткіліксіз болғандықтан, өсімдік индекстерінің көбінесе екі немесе одан да көп спектральды жолақтарды біріктіру арқылы дамиды. Өсімдік жамылғысы индексі - белгілі бір беткей аумағындағы өсімдіктер аймағының үлес мөлшері. Сонымен қатар зерттеу аймағының өсімдік жамылғысын анықтап, талдау үшін арақашықтықтан зерделеу (зондтау) туралы ақпараттар қолданылды. Уақыт пен кеңістік шектеулерімен арақашықтықтан зерделеу өсімдік жамылғысын жіктеуде кеңінен қолданылады.

Бұл жұмыста өсімдік жамылғысының үлесі NDVI бойынша бағаланған, ал өсімдік жамылғысының үлесі топырақта NDVI (NDVIS) және өсімдіктегі NDVI (NDVIV) арасындағы қатынастарды ескере отырып, өсімдік жамылғысының үлес салмағына байланысты бес класқа бөлінді. NDVI индексі арқылы өсімдік жамылғысының таралу аймақтары 2000 жылға дейін және 2000 жылдан кейінгі Landsat-5 ғарыштық сурет негізінде салыстырмалы түрде анықталды. ТСТ коэффициенттері арақашықтықтан зерделеу мәліметтерін қолдану арқылы шешілетін мәселелердің кең спектрінде қолданылады: су объектілерінің жағалау сызығын танудан бастап, орманның бұзылуын анықтауға дейін. Стрессті өсімдіктер топырақта тұздың болуының жанама белгісі болуы мүмкін. Тұзды топырақ әдетте нашар отырғызылған жерлермен сипатталады. Қалыпты дифференциалданған тұздылық индексі (NDSI) анықталды.

Түйін сөздер: деградация, шөлдену, ғарыштық суреттер, Landsat-5, NDVI.

\author{
А.Г. Габдыкадыр ${ }^{1}$, Г.Т. Исанова ${ }^{1,2}$, Е.Х. Какимжанов ${ }^{1}$, Лонг Ма $^{3}$ \\ ${ }^{1}$ Казахский национальный университет имени аль-Фараби, \\ Факультет географии и природопользования, Алматы, Казахстан; \\ ${ }^{2}$ Научно-исследовательский центр экологии и окружающей среды Центральной Азии, Алматы, Қазақстан; \\ ${ }^{3}$ Синьцзянский институт экологии и географии Китайской академии наук, Китай
}

\title{
АНАЛИЗ ДЕГРАДАЦИИ И ОПУСТЫНИВАНИЯ ПОЧВ ПУСТЫНЬ ЮЖНОГО ПРИБАЛХАШЬЯ С ПРИМЕНЕНИЕМ ГИС
}

Аннотация. Опустынивание и деградация почв представляют четкую картину глобальных экологических и социально-экономических проблем. На опустынивание влияют не только климатические факторы, нарушение рельефа поверхности вследствие дефляции и эрозии почвы и растительности, интенсивность ветровых процессов и другие природные факторы, но также антропогенные действия, такие как неэффективное использование пахотных и пастбищных земель и расточительное использование водных ресурсов. также оказывают негативное влияние на природу.

Опустынивание является результатом длительного исторического процесса, который приводит к неблагоприятным воздействиям природы и природы, которые изменяют характеристики усиливающей среды. Большая часть Казахстана находится в пустынном регионе, включая пустыни Южного Прибалхашья. Опустынивание территории обусловлено влиянием природных и антропогенных факторов на экосистему пустыни.

В последние годы экологическая ситуация в пустыне Южного Прибалхашья резко ухудшилась не только в результате регулирования речного стока, но и в результате антропогенного воздействия. В данной работе исследования рассмотрены результаты анализов пустынной растительности. Информация в спектральном диапазоне недостаточно для описания состояния растений, поэтому индексы растений часто развиваются путем объединения двух или более спектральных полос. Индекс растительного - это доля растительности на определенной площади поверхности. Кроме того, использовались материалы дистанционного зондирования для выявления и анализа растительного покрова исследуемой территории. Так как дистанционное зондирование с ограничениями по времени и пространству широко используется для классификации растительного покрова. В этой работе доля растительности была оценена с помощью индекса NDVI. Доля растительного покрова основана на взаимосвязи между NDVI (NDVIS) и NDVI (NDVIV) в почве. С помощью индекса NDVI зоны растительного покрова были определены на основе спутниковых снимков Landsat-5 (2006 г и 2011 г). Коэффициенты ТСТ применяются в самом широком спектре задач, решаемых с помощью данных ДЗ3: от распознавания береговой линии водоемов до определения нарушений лесов. Стрессовая растительность может быть косвенным признаком наличия соли в почвах. Засоленные почвы характеризуются плохо выраженным растительным покровам. Также был определен нормализованный разностный индекс засоленности (NDSI).

Ключевые слова: деградация, опустынивание, космические снимки, Landsat-5, NDVI.

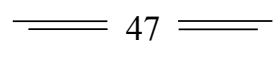


Information about authors:

Gabdykadyr Aikorkem, master student at the Al-Farabi Kazakh National University, Faculty of Geography and Environment, gabdykadyr@inbox.ru; https://orcid.org/0000-0002-4640-1980;

Issanova Gulnura, PhD in Natural Sciences (Physical Geography), scientific secretary at the Research Centerfor Ecology and Environment of Central Asia (Almaty) and PostDoc at the Al-Farabi Kazakh National University, gul_nur.777@mail.ru; https://orcid.org/0000-0002-4496-0463;

Kakimzhanov Yerkin is a PhD, lecturer at the Al-Farabi Kazakh National University; erka_7717@mail.ru; https://orcid.org/00000001-6454-681X;

Long $\mathrm{Ma}$ is an associate professor at Xinjiang Institute of Ecology and Geography, Chinese Academy of Sciences; https://orcid.org/0000-0001-8483-1554

\section{REFERENCES}

[1] Babkov A.A. (1867). On the progress of topographic research of Lake Balkhash and its coasts. J. Notes of the Empire of the Russian Geographical Society for General Geography. St. Petersburg, p. 337-338, (in Rus.).

[2] Mushketov I.V. (1886), Turkestan SPb., T.1. p. 102, (in Rus.).

[3] Fisher V. (1884). Lake Balkhash and the Ile river coasts. J. West Siberian Division of the Imperial Russian Geographical Society. Omsk, Book 6. P. 2-7,(in Rus.).

[4] Nikolsky A.M. (1885). Journey to the lake Balkhash to Semirechensk Oblast. J. West Siberian Division of the Imperial Russian Geographical Society. Omsk, Book 7. Issue 1. P. 12-17 (in Rus.).

[5] Meffert B.F. (1911). Sketch of the northern Balkhash and the coasts of western Balkhash: Department of Geography of Mathematics and Physical Geography Russian Geographical Society. St. Petersburg, p. 44 (in Rus.).

[6] Tazabekova E.T. (2012). Usen A. Formation of Anthropogenic Soils In The Agricultural Areas of The Southern Balkhash (South Kazakhstan). J. Bulletin of KazNU. Series geographic. Almaty, p. 45-52 (in Rus).

[7] Tilekova T., Oshakbaev M.T., Haustov A.P. (2016) Assessment of the geoecological state of Balkhash" - Geography and Natural Resources. № 1 p. 173-181, (in Rus).

[8] Paola Molinari (2014). A geographic information system (GIS) with integrated models: a new approach for assessing the vulnerability and risk of desertification in Sardinia-Italy.https://doi.org/10.1080/11287462.2014.894712 (in Eng.).

[9] Zolotokrylin A.N., Titkova T.B., Ulanova S.S., Fedorov N.L. (2013). Terrestrial and satellite studies of the productivity of pasture republics of Kalmykia with an affordable degree of degradation of plant communities (in Rus).

[10] Petrov K.M., Bananova V.A., Lazareva V.G., Unagaev A.S. (2016). Regional manifestation of global desertification in the north-west of the Caspian Sea(in Rus).

[11] Bondur V.G., Murynin A.B., Richter A.A., Shahramanyan M.A. Development of an algorithm for assessing the degree of soil degradation from a multispectral image (in Rus).

[12] Kubenkulov K.K., Naushabayev A.K., Rsymbetov B.A., Seytkali N. (2018).Water regime of anthropogenic-degraded sandy soils of desert rangelands and necessity of his regulation, NEWS OF THE NATIONAL Academy of Sciences of The Republic of Kazakhstan, Series of Agricultural Sciences, ISSN 2224-526X Volume 2, Number 44, 49-54. (in Eng.).

[13] Rsymbetov B.A., Kubenkulov K., NaushabaevA. Kh., Seitkali N. (2018). Hydrothermal regime of the centers of the mobile barchans formed as a result of anthropogenic degradation of sandy soils of deserts, NEWS OF THE NATIONAL Academy of sciences of the Republic of Kazakhstan, Series of Agricultural Sciences, ISSN 2224-526X Volume 1, Number 43, $74-78$ (in Eng.).

[14] Gvozdetsky N.A., Geldyeva G.V., Veselova L.N., Chupakhin V.M. (1979). Landscape map of the Kazakh SSR, 1: 2500000. Alma-Ata: F-ka. No. 7 GUGK (in Rus).

[15] Panichkin V.Yu., Miroshnichenko O.L., TrushelL.Yu., Zakharova N.M. (2017). Use of GIS Technology for assessment of natural underground water reserves of the quaternary aquifer system, South Balkhash artesian basin, NEWS OF THE NATIONAL Academy of sciences of the Republic of Kazakhstan, Series of Geology and Technical Sciences, ISSN 2224-5278 X Volume 1, Number 421, 102-111 (in Rus.).

[16] Ergaliev G.K., Zhemchuzhnikov V.G., Pirogova T.Ye. (2019). Cambrian of the North-Western Balkhash area, NEWS OF THE NATIONAL Academy of sciences of the Republic Of Kazakhstan, Series of Geology and Technical Sciences, ISSN $2224-5278$ Volume 5, Number 437, (2019). PP. 158-168, https://doi.org/10.32014/2019.2518-170X.138

[17] Kudekova T.K.(Eds). (2002). The current ecological state of Balkhash Lake basin. Almaty: Kanagat, p. 388. (in Rus). (in Rus.)

[18] Scientific and applied reference to the climate of the USSR. L: Gidrometeoizdat, 1989. series 3, book 1. P. 168-170,

[19] https://ru.wikipedia.org/wiki/Балхаш

[20] Lillesand, T.M. and R.W. Kiefer. (2004). Remote Sensing and Image Interpretation, fifth edition.John Wiley \& Sons, Inc., New York. (in Eng.).

[21] Kazakov G. (2011). Use of modishyperspectrometer data in the study of agriculture of Kursk region.

[22] Healey S.P., Cohen W.B., Zhiqiang Y., Krankina O.N. (2005). Comparison of Tasseled Cap - based Landsat data structures for use in forest disturbance detection. J. Remote Sensing of Environment. 97:301-3. (in Eng.).

[23] Elhag M, Bahrawi J. (2017). Soil salinity mapping and hydrological drought indices assessment in arid environments based on remote sensing techniques. Geoscientific Instrumentation, Methods and Data Systems 6(1) 149-158. (in Eng.).

[24] Abdelfattah M.A., Shahid S.A., Othman Y.R. (2009). Soil salinity mapping model developed using RS and GIS: a case study from Abu Dhabi, United Arab Emirates. (in Eng.).

[25] Browing D M, Duniway M C. (2011). Digital soil mapping in the absence of field training data: A case study using terrain attributes and semi-automated soil signature derivation to distinguish ecological potential. Applied and Environmental Soil Science, 421904, doi: 0.1155/2011/421904 (in Eng.).

[26] Azabdaftari A., Sunarb F. (2016). Soil salinity mapping using multitemporal landsat data. (in Eng.).

[27] Evdokimov S.I., MikhalapS.G. (2015). Determining the physical meaning of the combination of Landsat imagery channels for monitoring the state of terrestrial and aquatic ecosystems. 


\title{
Publication Ethics and Publication Malpractice in the journals of the National Academy of Sciences of the Republic of Kazakhstan
}

For information on Ethics in publishing and Ethical guidelines for journal publication see http://www.elsevier.com/publishingethics and http://www.elsevier.com/journal-authors/ethics.

Submission of an article to the National Academy of Sciences of the Republic of Kazakhstan implies that the work described has not been published previously (except in the form of an abstract or as part of a published lecture or academic thesis or as an electronic preprint, see http://www.elsevier.com/postingpolicy), that it is not under consideration for publication elsewhere, that its publication is approved by all authors and tacitly or explicitly by the responsible authorities where the work was carried out, and that, if accepted, it will not be published elsewhere in the same form, in English or in any other language, including electronically without the written consent of the copyright-holder. In particular, translations into English of papers already published in another language are not accepted.

No other forms of scientific misconduct are allowed, such as plagiarism, falsification, fraudulent data, incorrect interpretation of other works, incorrect citations, etc. The National Academy of Sciences of the Republic of Kazakhstan follows the Code of Conduct of the Committee on Publication Ethics (COPE), and follows the COPE Flowcharts for Resolving Cases of Suspected Misconduct (http://publicationethics.org/files/u2/New_Code.pdf). To verify originality, your article may be checked by the originality detection service Cross Check http://www.elsevier.com/editors/plagdetect.

The authors are obliged to participate in peer review process and be ready to provide corrections, clarifications, retractions and apologies when needed. All authors of a paper should have significantly contributed to the research.

The reviewers should provide objective judgments and should point out relevant published works which are not yet cited. Reviewed articles should be treated confidentially. The reviewers will be chosen in such a way that there is no conflict of interests with respect to the research, the authors and/or the research funders.

The editors have complete responsibility and authority to reject or accept a paper, and they will only accept a paper when reasonably certain. They will preserve anonymity of reviewers and promote publication of corrections, clarifications, retractions and apologies when needed. The acceptance of a paper automatically implies the copyright transfer to the National Academy of sciences of the Republic of Kazakhstan.

The Editorial Board of the National Academy of sciences of the Republic of Kazakhstan will monitor and safeguard publishing ethics.

Правила оформления статьи для публикации в журнале смотреть на сайте:

www:nauka-nanrk.kz

\author{
ISSN 2518-1483 (Online), ISSN 2224-5227 (Print)
}

http://reports-science.kz/index.php/en/archive

Редакторы: М. С. Ахметова, Г. Б. Халидуллаева, Д. С. Аленов

Верстка на компьютере А.М. Кульгинбаевой

Подписано в печать 07.04.2020.

Формат 60x881/8. Бумага офсетная. Печать - ризограф.

11 п.л. Тираж 500. Заказ 2. 